\title{
Clinical and Sociodemographic Profile of Patients with Priapism Treated at a University Hospital
}

\author{
Mateus Henrique da Silva Faria ${ }^{1}$, Ana Flávia Azevedo Querichelli ${ }^{1}$, \\ Luis César Fava Spessoto ${ }^{2}$, Fernando Nestor Fácio Junior ${ }^{2}$
}

\author{
${ }^{1}$ Undergraduate Student, São José Rio Preto School of Medicine (FAMERP), Brazil \\ ${ }^{2}$ Department of Urology, São José Rio Preto School of Medicine (FAMERP), Brazil
}

\begin{abstract}
Priapism is urological emergency that consists of a prolonged erection for more than four hours, independently of sexual stimulation. Due to its low incidence, the pidemiology is not fully known. The aim of the present study was to investigate the clinical and sociodemographic profile of patients with priapism treated at a university hospital. A retrospective, cross-sectional study was conducted involving the records of patients with priapism treated at an emergency urological service between January 2011 and August 2018. The variables analyzed were age, ethnicity, marital status, previous adverse health conditions, the use of recreational drugs and the number of visits to the hospital by each patient. Forty-two patients with priapism were studied, totaling 178 hospital visits. The analysis of the charts revealed age ranging from 15 to 85 years, with the majority of cases (72\%) occurring between 20 and 50 years of age. Regarding ethnicity and marital status, $64 \%$ were self-declared white, $22 \%$ were self-declared black, $43 \%$ were married and 33\% were single. Approximately $52 \%$ of the patients $(\mathrm{n}=22) \mathrm{had}$ a previous adverse health condition. Among these individuals, eight $(36 \%)$ had a blood disease, the most frequent of which was sickle cell anemia $(n=5 ; 62.5 \%)$. Eleven $(26 \%)$ patients reported using recreational drugs and $74 \%$ made no use of drugs. Analyzing the number of hospital visits per patient, 57\% were treated for a single episode and $43 \%$ $(n=18)$ returned more than once to the urological emergency service with the same condition. Based on the present findings obtained from a university hospital, sickle cell anemia was the most frequent condition among the patients. No significant association was found between the use of recreational drugs and the occurrence of priapism. The most affected age group was 20 to 40 years, with a predominance of white, married men.
\end{abstract}

Keywords: Erectile Dysfunction, Ischemic, Non-Ischemic, Priapism

\section{INTRODUCTION}

Priapism is defined as a prolonged, persistent erection not related to sexual stimulation and generally painful. Divergent opinions are found regarding the duration of the erection, the general consensus is longer than four hours. ${ }^{1}$ The first reported case was published in 1824, but the term first emerged in 1616 in reference to Priapus of Greek mythology, god of sexuality, fertility and seduction. ${ }^{2}$

Despite the limited data, the incidence of priapism is estimated to be 1.1-1.5 for every 100,000 men per year, ${ }^{3}$ with peaks in particular age groups. The main etiological factors are sickle cell enemia, ${ }^{4}$ intracavernous injection of phentolamine, prostaglandin or papaverine for the treatment of erectile dysfunction, perineal trauma, ${ }^{5}$ diabetes, urological tumors and the use of medications, such as antidepressants, anti-hypertensive agents and anticoagulants. $^{6}$ More severe cases can lead to fibrosis of the penile tissue and consequent erectile dysfunction. ${ }^{7}$ Therefore, emergency treatment is important.
Although its physiopathology is not fully known, priapism is classified into two types: ischemic and non-ischemic. Ischemic (low flow or veno-occlusive) priapism is caused by an imbalance in the mechanisms of vasoconstriction and vasodilatation, leading to penile compartment syndrome, which is characterized by hypoxia, hypercapnia and acidosis. With prolonged exposure to this condition, the smooth muscles of the penis can suffer irreversible damage, such as tissue destruction and fibrosis. The non-ischemic (high-flow or arterial) type occurs with unregulated arterial flow, generally due to trauma and the consequent formation of an arterial fistula. In such cases, the erection is not completely rigid and not associated with pain. ${ }^{8}$ Another clinical presentation of priapism is the rare, recurring, low- 
flow form characterized by periods of prolonged, painful erection initiating during sleep. ${ }^{9}$

The diagnosis is based on the clinical history, physical examination and gasometric analysis of the corpora cavernosa for the determination of the type of priapism. ${ }^{10}$ With the ischemic type, metabolic acidosis is expected, with a low concentration of oxygen $\left(\mathrm{pH}<7.25 ; \mathrm{pO}_{2}<30 \mathrm{mmHg} ; \mathrm{pCO}_{2}>60\right.$ $\mathrm{mmHg}$ ). With the non-ischemic type, gasometric findings are of the arterial type without acidosis $(\mathrm{pH}$ near 7.35; $\left.\mathrm{pO}_{2}>90 \mathrm{mmHg} ; \mathrm{pCO}_{2}<40 \mathrm{mmHg}\right){ }^{11}$ Complementary exams can confirm the classification and indicate the etiological agent, such as hemogram, coagulogram and Doppler ultrasound to determine signs of arteriovenous fistula. Moreover, magnetic resonance may be used to evaluate the viability of the corpora cavernosa and spongiosa in cases of prolonged ischemic priapism. ${ }^{12}$

The aim of treatment is penile detumescence, pain relief and the preservation of erectile function. ${ }^{13}$ The ischemic form is considered an emergency that requires immediate intervention. For such, the stored blood is drained and intracavernous injection of sympathomimetics is performed, for which phenylephrine is the drug of choice. In refractory cases, a cavernospongiosal surgical shunt may be performed. ${ }^{14}$ For the non-ischemic type, the initial conduct is "wait-and-see", with the expectation of spontaneous resolution. If this does not occur, a selective arterial embolization is the treatment of choice, ${ }^{15}$ with surgery only considered as a last resort. For recurring cases, treatment for acute episodes is the same as that for the ischemic form, but the main objective of treatment is the prevention of further episodes with the use of drugs, such as GnRH agonists, anti-androgens, estrogens, digoxin and gabapentin. Although effective, these drugs have side effects. ${ }^{16}$ The purpose of the present study was to investigate the clinical and sociodemographic profile of patients with priapism treated at a university hospital.

\section{PATIENTS AND METHODS}

A retrospective, cross-sectional study was conducted involving the records of patients with priapism treated at the emergency urological service of the São José do Rio Preto University Hospital (state of São Paulo, Brazil) between January 2011 and August 2018. The variables analyzed were age, ethnicity, marital status, previous adverse health conditions, the use of recreational drugs and the number of visits to the hospital per patient. Data were collected through a survey of the hospital electronic patient chart system and kept confidential to ensure the anonymity of the patients. This study received approval from the institutional review board.

\section{RESULTS}

Forty-two patients with priapism were studied, totaling 178 hospital visits. The analysis of the charts revealed age ranging from 15 to 85 years (mean: 42.7; standard deviation: 16.6 years), with the majority of cases (72\%) occurring between 20 and 50 years of age and a peak of 17 patients between 31 and 40 years of age (Figure 1). Between the extremes of age, 11 patients $(26 \%)$ were older than 50 years and only one was younger than 20 years of age.

Regarding self-declared skin color, $64 \%$ were white, $22 \%$ were black, $14 \%$ were brown and one patient did not declare his skin color. A total of $43 \%$ were married, $33 \%$ were single, $14 \%$ were in a stable union, $2 \%$ were widowers and $7 \%$ were divorced (Table 1).

Approximately $52 \%$ of the patients $(\mathrm{n}=22)$ had a previous adverse health condition (Table 2). Among these individuals, eight (36\%) had a blood disease, the most frequent of which was sickle cell anemia (n $=5 ; 62.5 \%$ ). Non-hematological conditions included systemic arterial hypertension (18\%), diabetes mellitus (13\%), erectile dysfunction (13\%), schizophrenia (9\%), multiple sclerosis (4.5\%), epilepsy $(4.5 \%)$ and chronic myeloid leukemia (4.5\%). Two patients had a history of stroke and 20 patients reported no previous adverse health conditions.

Regarding the use of medications, 11 (26\%) patients reported using recreational drugs and $74 \%$ made no use of drugs. Analyzing the number of hospital visits per patient, $57 \%$ were treated for a single episode and $43 \%(\mathrm{n}=18)$ returned more than once to the urological emergency service with the same condition. Among these individuals, five $(27.7 \%)$ had a previous blood disease: four with sickle cell anemia (80\%) and one with hemoglobin C disease. Moreover, two patients with recurrent episodes $(11.1 \%)$ had hypertension, one $(5.5 \%)$ had diabetes, one $(5.5 \%)$ had schizophrenia and one $(5.5 \%)$ had epilepsy. Eight patients with recurrent episodes of priapism $(44.4 \%)$ had no previous adverse health condition.

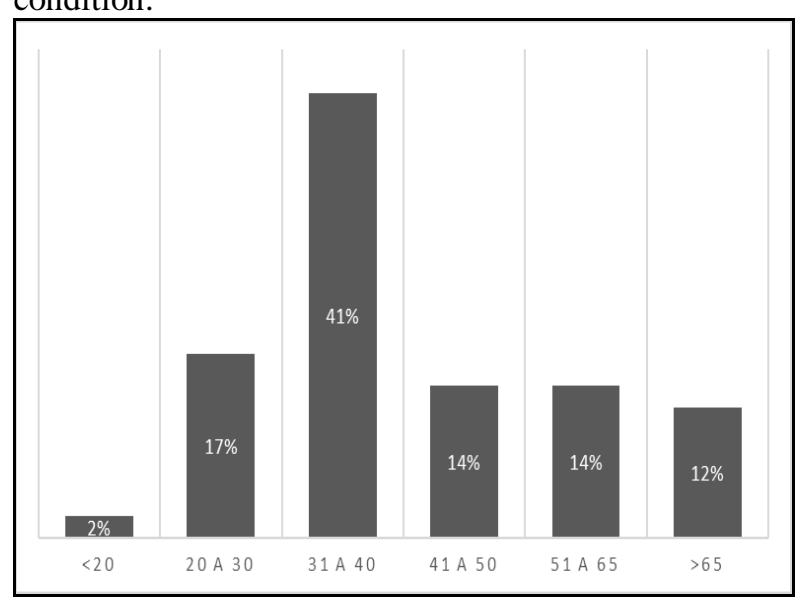

Figure 1 - Percentage distribution of age groups of patients with priapism. 
Table 1 - Distribution of marital status and race of patients with priapism

\begin{tabular}{lcc}
\hline Marital status & N & $\%$ \\
\hline Married & 18 & 43 \\
Single & 14 & 33 \\
In stable union & 6 & 14 \\
Divorced & 3 & 7 \\
Widowed & 1 & 2 \\
\hline Race & & \\
White & 27 & 64 \\
Black & 9 & 22 \\
Brown & 5 & 11.1 \\
Undeclared & 1 & 2.3 \\
\hline
\end{tabular}

$\mathrm{N}=$ number of indivi

Table 2 - Distribution of previous adverse health conditions among patients with priapism

\begin{tabular}{llc}
\hline Condition & $\mathrm{N}$ & $\%$ \\
\hline Sickle cell anemia & 5 & 22.7 \\
Hypertension & 4 & 18.1 \\
Erectile dysfunction & 3 & 13.6 \\
Diabetes mellitus & 3 & 13.6 \\
Schizophrenia & 2 & 9.0 \\
Chronic myeloid leukemia & 1 & 4.5 \\
Hemoglobin C disease & 1 & 4.5 \\
Alpha thalassemia minima & 1 & 4.5 \\
Multiple sclerosis & 1 & 4.5 \\
Epilepsy & 1 & 4.5 \\
\hline
\end{tabular}

$\mathrm{N}=$ number of individuals

\section{DISCUSSION}

Analyzing the present results, the largest number of patients was between 20 and 50 years of age, with a peak incidence between 30 and 40 years of age. This finding is in agreement with data reported in the literature, which describes a bimodal incidence: one between five and 10 years due mainly to the occurrence of sickle cell anemia in the pediatric population and one between 20 and 50 years, the main cause of which is intercavernous medication. ${ }^{17}$

The majority of the present sample was white. This is in disagreement with data reported in the literature, which describes a greater incidence of priapism among black men with sickle cell anemia. ${ }^{18}$ The greater occurrence of priapism among white men in the present study may have been due to the small sample size.

An association was found between priapism and blood diseases in $36 \%$ of patients. The association between sickle cell anemia and priapism is well documented in the literature. ${ }^{19,20}$ Indeed, this condition accounted for $62 \%$ of the patients with blood diseases. Approximately half of the patients in the present study had no previous adverse health condition. Regarding the relationship between the use of recreational drugs and the occurrence of priapism, only $26 \%$ of the patients reported having this behavior.

\section{CONCLUSIONS}

Based on the present findings obtained from a university hospital, sickle cell anemia was the most frequent condition among the patients with priapism. The most affected age group was 20 to 40 years, with a predominance of white, married men. No significant association was found between the use of recreational drugs and the occurrence of priapism.

\section{REFERENCES}

1. Silveira JCT, Hachul M. Priapismo: urgência urológica que pode causar disfunção erétil. Emergência clínica 2011;6:106108.

2. Hernández Cruz, FJ. Priapismo. Arch Hosp Univ General Calixto García 2015;3:2.

3. Eland IA, van der Lei J, Stricker BH, Sturkenboom MJ. Incidence of priapism in the general population. Urology 2001;57:970-972.

4. Reddy AG, Alzweri LM, Gabrielson AT, Leinwand G, Hellstrom WJG. Role of penile prosthesis in priapism: a review. World J Mens Health 2018;36:4-14.

5. Song PH, Moon KH. Priapism: current updates in clinical management. Korean J Urol 2013;54:816-823.

6. Villegas J, Corchuelo C, Cuevas A, Medina R. Priapismo isquémico como presentación de leucemia mieloide crónica. Arch Esp Urol 2014;67:708-711.

7. Montague DK, Jarow J, Broderick GA, Dmochowski RR, Heaton JP, Lue TF, et al. Members of the Erectile Dysfunction Guideline Update Panel; American Urological Association. American Urological Association Guideline on the management of priapism. J Urol 2003;170:1318-1324.

8. Rodríguez Villalba R, Garcia S, Puigvert Martínez A, Pomerol I Montseny JM, Munárriz R. Priapism. Actas Urol Esp 2005;29:961-968. 
9. Facio FN, Ayres D, Spessoto LCF. Priapismo: novas estratégias de tratamento. Arq H Ellis 2010;6:16-19.

10. Vicari P, Figueiredo MS. Priapismo na doença falciforme. Rev Bras Hematol Hemoter 2007;29:275-278.

11. Muneer A, Alnajjar HM, Ralph D. Recent advances in the management of priapism. F1000 Research 2018, 7(F1000 Faculty Ver):37 Last Updated: 2018.

12. Hatzimouratidis K, Giuliano F, Moncada I, Muneer A, Salonia A, Verze P. EAU Guidelines on erectile dysfunction, premature ejaculation, penile curvature and priapism. EAU Guidelines, 2016

13. Diretrizes Guia de Bolso: Uma Referência Rápida para os Urologistas. 2017 American Urological Association Education and Research. Priapismo, 2010.

14. Manjunath AS, Hofer MD. Urologic emergencies. Med Clin North Am 2018;102:373-385.

15. Nardozza Jr A, Campos RSM, Ruiz S. MANU: Manual de urologia

2010

São Paulo: PlanMark; 2010
16. Levey HR, Kutlu O, Bivalacqua TJ. Medical management of ischemic stuttering priapism: a contemporary review of the literature. Asian J Androl 2012;14:156-163.

17. Ferreira V, Matos A, Carvalho LF, Azevendo N, Reis D, Loureiro L, et al. Treatment of ischemic priapism with Grayhack surgery: case report. Angiol Cir Vasc 2016;12:211213.

18. Felix AA, Souza HM, Ribeiro SBF. Aspectos epidemiológicos e sociais da doença falciforme. Rev Bras Hematol Hemoter 2010;32:203-208.

19. AlDallal S, AlDallal N, Alam A. Sickle cell-induced ischemic priapism. Cogent Med 2016;3:1

20. Castro MO, Meléndez BJE, Pedro SIE, Mirabal FA Rodríguez MA. Epidemiological, diagnostic and therapeutical characterization of patients with priapism. MediSan 2015;19:1238-1247.

21. Sönmez MG, Öztürk Sönmez L, Taşkapu H, Kara C, Dündar $\mathrm{Z}$, Göğer $\mathrm{Y}$, et al. Etiological factors and management in priapism patients and attitude of emergency physicians. Arch Ital Urol Androl 2017;89:203-207. 